\title{
Design for sustainable supply chain: the case of specialty coffees production
}

\author{
lana Giesbrecht Castello Branco, Andréa Cristina dos Santos \\ Universidade de Brasilia - UnB \\ e-mails: iana.giesbrech@gmail.com; andreasantos@unb.br
}

\begin{abstract}
The parameters that distinguish specialty coffees have to do with economic, social and environmental sustainability of their production in the sense of fostering greater fairness in the relations among the links in the supply chain. However, very little research has been done and very few guidelines have been constructed that would indicate how to adopt Sustainable Supply Chain Management practices and how to proceed. In this context, this research aims to identify guidelines capable of describing the sustainable supply chain of specialty coffee production on small farms in Brazil. The specialty coffees studied in the present research are of high quality rated above the minimum for exportation. It was also observed that farmers have managed two important things: developed relations of fidelity with trading companies so they can accompany the production; and organized themselves and disseminated costs, strengthened cultural patterns and positioned themselves better in the market.
\end{abstract}

Keywords: coffee production, sustainable supply chain, specialty coffee, Brazilian coffee, small producers.

\section{Introduction}

Organic, shade, gourmet and fair trade are the terms that define the specialty coffees that have gone to the top of the market in recent years. The parameters that distinguish specialty coffees have to do with economic, social and environmental sustainability of their production in the sense of fostering greater fairness in the relations among the links in the supply chain. Despite the attention being paid to the adoption of Sustainable Supply Chain Management (SSCM) practices, according to Kang et al. (2012), very little research has been done and very few guidelines have been constructed that would indicate how to adopt them and how to proceed.

In order to address the lack academic production, EMBRAPA Cerrado (the unit of the Brazilian Agricultural Research Corporation based in Brazil's Central-western macro-region) has been conducting a series of experiments in association with farmers targeting the implantation, management, processing and commercialization of their production, as well as diffusing information of their work in retrieving and improving the traditional system of shade coffee production.

The work is being undertaken alongside a group of 16 farming families in the micro-region known as the Upper Pardo River (Alto Rio Pardo) in the northern part of the state of Minas Gerais, Brazil. Initial results include an increase in production and productivity, diversification of production and family income, as well as improved conservation of natural resources, food security and the local organization (CARRARA, 2009).

This article reports part of that larger EMBRAPA research which aims to identify guidelines capable of describing the sustainable supply chain of specialty coffee production on the small farms of Minas Gerais and Parana states.

Overall, research methodology was of a descriptive nature and used the following implementation techniques: bibliographic survey, documental research and case study, in alignment with Gil (2002). Accordingly, research was divided into three stages. The first stage consisted of an exploratory study in the northern part of the state of Minas Gerais designed to gather essential information for the project. The second was a systematic study of the respective literature in order to identify patterns that could be replicated in future work. In the third stage, the models, practices and tools studied were observed, discussed and analysed in the context of coffee growing being made using the selected production processes.

The first stage unfolded in response to an invitation from EMBRAPA Cerrado to conduct an exploratory study in the northern region of Minas Gerais. The trip to the region took place in December 2014 and involved visits and interviews with coffee farmers in that region and two cooperatives 
and their representatives as well as visiting the small local agro-industry.

The exploratory study of the first stage of the research highlighted the need to insert sustainability in the coffee supply chain (CASTELLO-BRANCO, 2014). Finally, the third stage of which the present article is part, aimed to analyse the guidelines that describe a sustainable specialty coffees supply chain, especially one appropriate for small farms, based on the selected case study.

The underlying methodology for this article was based on the first two stages of the larger research - bibliographic and documental research - and presents a case study involving two regions of Brazil. The article has been divided up by topics as follows: after introduction (1.0) comes a review of the literature (2.0) on which the project is based followed by an account of the methodology (3.0) used to conduct the case study. The fourth topic (4.0) will present and discuss the results achieved by the case study. The last topic (5.0) will set out the article's conclusions.

\section{Background}

This topic has been organized based on: Supply Chain Management, Sustainable Supply Chain Adoption and Management, and the Coffee Supply Chain. Each one is afforded a separate description in the order set out here.

In 2006, Douglas Lambert published a paper on the Global Supply Chain Forum (GSCF) model for supply change management. It emphasizes the inter-relations that exist and the need to work on all the processes in order to achieve successful supply chain management. According to Kieckbusch (2010), the main feature of this approach is the effort to standardize the business processes as means to fostering chain integration.

The same author also states that supply change management is the integration of all the main business processes between the final consumer and the supplier, involving products, services and information, that add value for the consumers and all the other interested parties (LAMBERT, 2006). That being so, the three structural elements of the supply chain are: the structure of the supply chain network, the business processes and the management components.

Importance has been increasingly attributed to a sustainable approach based on harmonizing social, ecological and economic objectives. Before the use of the term 'sustainable', Ignacy Sachs referred to it in his works as 'eco-development' (SACHS, 1997). According to Diniz (2008), when Sachs proposed the concept he was referring to new kinds of development, production and lifestyles based on the conditions determined by the ecosystems and the management of resources and duly adapted to each region or ethnic diversity or even to the participative management capabilities of populations (SACHS, 2004).
Similarly, at the end of the 1990s, the concept triple bottom line (TBL) was proposed. In his book, Elkington (2004) states that the term was created in 1994 based on the observation that social and economic dimensions of the agenda proposed by the 1987 Brundtland Report (WORLD..., 1987) called for a much more integrated approach in the quest for a veritable environmental progress. Thus TBL was to become the most widely diffused representation of the sustainable development concept, referring to the integration of the environmental, social and economic dimensions [of development].

In short, whereas in the past supply chain management focused on obtaining an efficient and agile production system and on the passage of raw materials through the chain to the final consumer, currently environmental and social considerations have acquired considerable importance. That has raised the question as to how industry can respond to the challenge of sustainability (MCKONE-SWEET, 2004).

Finally, management of a sustainable supply chain requires the establishment of certain values and ethics in every organization, in addition to an efficient, flexible 'green' environment and strategic corporate alignment with sustainable development. If those measures are taken, then the network is effectively protected from environmental and social threats and possible risks (TEUTEBERG; WITTSTRUCK, 2010).

Lastly, the aspects associated to the insertion of the concepts of sustainability described above in such a way as to transform companies' Supply Chains into Sustainable Supply Chains are set out in the next section. Emphasis is on mechanisms, practices and tools that encourage the adoption of Sustainable Supply Chain Management.

\subsection{Adoption of sustainable supply chain management}

Gonçalves and Neves (2015) point out the lack of consensus as to what practices companies should adopt. Those authors group possible practices in the categories of Internal Environment Management, Eco-design and Green Operations. Those practices, together with reverse logistics, had previously been presented by Zhu, Sarkis and Lai (2008).

The authors also explain that cooperation with clients and investment recovery are practices inside the Sustainable Supply Chain context. The concepts those authors discussed will be addressed in the topics that follow.

Labegalini's (2010) concept of environmental management sees it as the administration of economic and social activities by utilizing renewable natural resources with a view to using practices that ensure biodiversity conservation and preservation, the recycling of raw materials and the reduction of the impacts on natural resources generated by human activities. 
Furthermore, environmental management encompasses the process of applying innovation throughout the organization as a means to achieving sustainability, reducing the volumes of residues, fostering social responsibility and guaranteeing competitive advantage by means of continuous learning and achieving development through the wide outreach of their environmental objectives and strategies, all totally integrated to the organization (HADEN; OYLER; HUMPHREYS, 2009).

Internally, the practice of environmental management corresponds to certain activities in the daily round of companies that are directed at achieving environmental improvements such as support for them provided by middle and top management; inter-functional cooperation for the implementation of environmental improvements; development of an environmental management system; environmental auditing and the proposition of environmental goals (ZHU; SARKIS; LAI, 2008).

Creating eco-efficient products without jeopardizing cost patterns or restricting manufacture time is among the objectives of the eco-design concept which is also known as Design for Environment and Environmentally Conscious Design. According to Graedel and Allenby (1995), ecodesign is a practice that consists of integrating environmental aspects to product development processes alongside the regular engineering and processing procedures.

Two Brazilian regulatory norms, ABNT ISO/TR 14062 (ASSOCIAÇÃO..., 2002) and NBR/ISO 14006 (ASSOCIAÇÃO..., 2011), describe eco-design as being the integration of environmental aspects to product development concepts with the intention of reducing environmental impacts generated during the product's life cycle. Thereby leading to continuous improvement in environmental performance by means of technological innovation and to organizational improvements represented by increased competitiveness and better relations with clients and other interested parties.

As mentioned previously, Green Operations are considered to be those that involve practices that stimulate the adoption of Sustainable Supply Chains.

Gonçalves and Neves (2015) classified Green Operations into the categories of green production, green purchasing, green manufacturing, reverse logistics and waste management.

Green production is considered to be an intervention in production processes to ensure that they make use of low impact materials and are highly efficient and that they generate little or no waste or pollution. In an analogous manner, green manufacturing embraces environmental aspects and the efficient use of resources in the entire length of the supply chain, but with greater emphasis on the management associated to the manufacturing technology. The difference is that the former acts directly on the production processes while green manufacturing specifically targets the technology used in them (GONÇALVES; NEVES, 2015).

In turn, reverse logistics is the process of planning implementing and controlling the efficient flow and low cost of obsolete materials which are in inventory processes and of goods after their useful lifetime has expired. It embraces everything from the point of consumption to the point of origin, with aim of recapturing value or disposing of the materials in an adequate manner (SHERIFF; GUNASEKARAN; NACHIAPPAN, 2012).

Lastly, Zsidisin and Siferd (2001) define Green Purchasing as a set of policies, actions and relations formed in response to environmental concerns which affect the form of selection, assessment and development of suppliers. Min and Galle (2001) state that the object of Green Purchasing is to reduce the use of materials, reduce waste and foster the recycling of products.

Cooperation with clients is presented in the literature as being an exchange of knowledge among the parties which allows for the planning and definition of goals associated to environmental progress (ELTAYEB; ZAILANI; RAMAYAH, 2011). Vachon and Klassen (2006) propose that such cooperation is associated to the product's performance in the aspect of its conformity with the requirements of durability and the inclusion of environmental quality in the materials. According to Zhu, Sarkis and Lai (2008) that concept includes eco-design, cleaner production and green packaging.

At this moment, in the light of the underlying structure of this paper, as set out above, it is necessary to analyse in depth the production sector of the specialty coffees sector that is the object of this study. Accordingly, the following item will be an introduction to the section on the various different production systems adopted by the sector.

\subsection{Specialty coffees supply chain}

According to the Brazil Specialty Coffee Association, specialty coffees can be classified into coffees with a certified origin when the coffee in question is associated to the local characteristics of the local Terroir, gourmet coffee - in this case Arabic coffee in which there are practically no defects in the beans and the sieve grade is equal to 16 or above; organic coffee which is in alignment with the precepts of organic agriculture but without jeopardizing the quality of the grains and, lastly, the Fair Trade coffee which is when the socio-environmental standards in green bean production are duly respected (BRAZIL..., 2013).

The coffee production process is divided into three stages - the pre-harvest, the post-harvest and the commercialization of the product. The first stage, in turn, consists of planting, cultivating and finally reaping. Within that first stage there are such activities as the preparation of the land, the 
preparations of the seedlings, the establishment of the coffee trees, management of the green fertilizer and the live and dead cover, management of pesticides and pest and disease control, irrigation and other activities (EMPRESA..., 2006; REVISTA..., 2006).

In the second stage, according to the same authors, after the coffee beans have been harvested and stored, there is the work of cleaning the green beans and transporting them to the area where they will be washed. After that comes a separation process, drying, storage and, lastly, accommodation in sacks (EMPRESA..., 2006; REVISTA..., 2006).

The last stage altogether refers to the further trading of the beans in sacks. For that they need to be processed, blended, roasted, grounded, packed, stored, transported and sold. This stage also embraces the activities of certification and quality control (EMPRESA..., 2006; REVISTA..., 2006).

In their work, Maria et al. (2015) gave a generic description of the questions involved in the coffee supply chain. Starting with the question of raw materials, they mention the various activities in preparing the seedlings and the soil prior to the actual planting of the coffee bushes. They then describe the coffee plantation itself with special attention to harvesting and transportation of production. The next stage of processing involves preparatory processes such as drying the grains and other aspects as the layout of the warehouses in which processed coffee ready for consumption is stored. Finally, they describe the commercialization stage when orders are dispatched and, in some cases, intermediaries handle the product.

There are various management practices designed to make coffee production more sustainable whenever possible, among them, shaded agroforestry type production, organic production, agro-ecological production, agricultural socio-environmental certification and geographical indications.

Shaded agroforestry production systems, according to Gama-Rodrigues et al. (2006), combine the production of agricultural crops with the planting of fruit trees or forest species and the raising of livestock, all in the same area and they adopt management techniques that are compatible with the agricultural practices of the local population.

On some of the properties visited as part of the present research, coffee is produced in a consortium with other species such as Inga trees (inga flagelliformis, inga cylindrica and inga sellowiana) thereby qualifying their production as agroforestry type. In the view of Mancuso, Soratto and Perdoná (2013), the shade formed by the trees in the coffee plantation leads to a slower maturing of the beans and various countries use the technique to produce specialty coffees.
Apart from the shade system, the coffee industry has the option of adopting organic production systems. Moreira (2004) defines organic production as being a crop and livestock production system that does not make use of synthetic materials that persist in the environment after use and, furthermore, one that adopts the principle of recycling organic material and maintaining the balance of nature. Such systems may incorporate animals adapted to them and they consider the human being as part of the production organism.

According to Altieri (2009), agroecology offers a methodological working structure that contemplates agro-ecosystems as being an approach to production that integrates agronomic, ecological and socio-economic principles to a broad understanding and assessment of the effect technologies have on agricultural systems and on society as a whole.

Agroecology is a science that develops a series of ecological principles applied to the management of production systems with a view to ensuring their sustainability and guaranteeing that they are environmentally healthy, socially fair and economically viable. Outstanding among the ecological principles are: maintaining biodiversity; incrementing biological activity of the soil; recycling nutrients; and ensuring genetic diversity (REDE..., 2007).

Inserted in the context of the various coffee production management systems portrayed so far in this paper are certification schemes that attest to the systems' direct or indirect respect for individuals, the environment, communities and especially their compliance with the established quality criteria.

The valuation and classification of commodity coffee only analyses the final product, taking into account the number of grain defects, the size of the grains and the quality of the beverage. In the case of differentiated coffees, specialty coffees and coffees with certified origins that are the object of this article, however, the markets are more demanding and the customer requires a product that has real quality, which does not necessarily have to do with the beverage or defects in the grains but, much more, with the production system (MOREIRA, 2004).

Lima, Keppe et al. (2008) consider that socialenvironmental agricultural certifications are market tools created in a context of valuing social and environmental standards in the agricultural production chain and that their function is to transmit the image of a differentiated product to the consumers.

Adeodato (2009) states that for a certification scheme to be able to attest the social-environmental message of any goods or services it needs to be technically conscious, non-discriminatory and voluntary. Every effort must be made to see that the operations being certified correct errors and review conducts in order to attain compliance with all 
the respective norms and to achieve continuous, progressive improvements.

Some examples of certification seals used by coffee growers are: UTZ Certified, Café do Cerrado, Fairtrade, Rainforest Alliance, Certifica Minas and 4C (NEGREIROS, 2011).

The benefits that accrue from the regulation of Geographical Indication fall into three different spheres. In the operational sphere, there is the stimulus to improve product quality and the identification by the consumer of product elaboration, production and manufacturing methods. In the cultural sphere, the benefits of Geographical Indications are even more visible: the generation of producer satisfaction, the enhanced valuing of the territory and of local knowledge and the contribution they make towards preserving agricultural production diversification and the products' particularities and personalities; all of those constitute a heritage and an asset for each region and country where they occur (BRASIL, 2014).

\section{Research methodology}

In any case study, one of the first tasks is to select the units of analysis. In this case two typical specialty coffee producing regions were identified as targets for the study. In both of them every effort was made to address the strategic links in the supply chain so as to get up to date information regarding the local organization of specialty coffee production.

To obtain some of the desired information, it was understood that, in the light of the different role of each one in the chain, it was important to interview different actors. After a review of the general scenario of the research it was decided to interview actors that are part of the supply chain with the following profiles: a development manager from the state of Parana, a coffee seed and coffee producer from the state of Minas Gerais, and three coffee producers from the state of Minas Gerais.

The first interviews were with a coffee seed and coffee producer in the region of the State of Minas Gerais known as Cerrado Mineiro, which appears in the Identification of Local Origin, and another with a coffee producer from the region known as Zona da Mata Mineira, in the east of that state. Both of them are members of the local association. In addition, two coffee farmers from the southern part of the state were interviewed to represent the question of Indication of regional origin. Following that, the study focused on the northern part of the state of Parana in the person of a regional coffee grower and also the administrator of the main project fostering development of the activity currently being unfolded in that area.

In every case, only medium-sized or small rural properties were considered. The research did not include big landholders with large-scale production. Also, in all the interviews was only gathered information on aspects related to specialty coffees as classified by the Brazil Specialty Coffee Association (BRAZIL..., 2013).

Figure 1 has been based on the work of (EMPRESA..., 2006; REVISTA..., 2006) and it delineates the frontiers between specialty coffee Supply Chain stages and identifies the actors inserted in each one of them. Six stages are presented: materials, production, green coffee, roasted/ground coffee, trading and consumption.

It can be seen however, that instead of listing all the potential suppliers, it was decided to identify which materials would be used in the following stages because it was felt that in some chains there are several suppliers for each one of the materials while in others, a single actor delivers them all.

The second stage, as shown in Figure 1, in addition to identifying the primordial participation of the coffee grower as such, shows which are the main processes inserted in the chain. However, it must be borne in mind that given the size

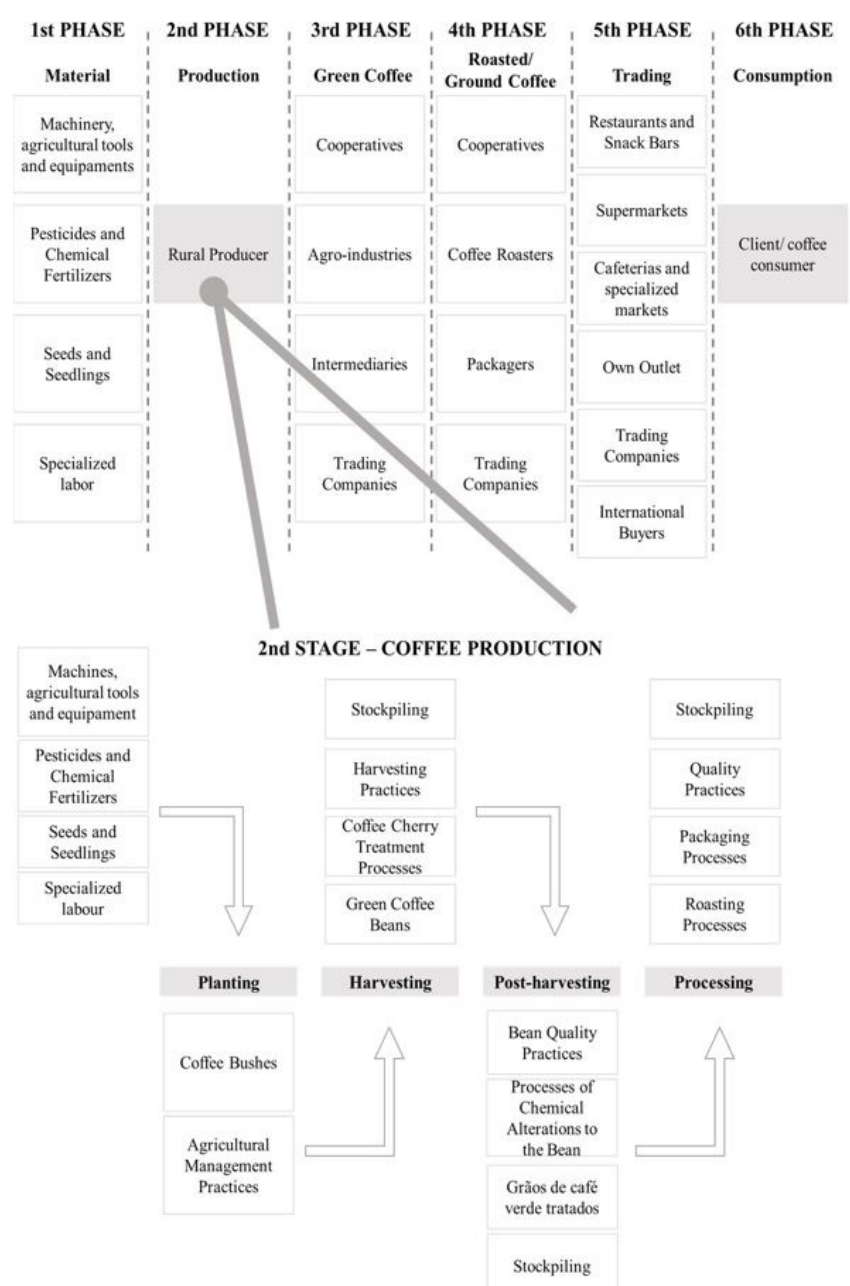

Figure 1. Coffee Supply Chain Structure. Source: Elaborated by the authors. 
of the coffee growers targeted by the research there may be some of them that do not conduct all the processes identified within the limits of their own installations. However, it is the producer's responsibility to pass on the coffee duly prepared (hulled, decoupled or demucilaged) to the next link in the chain, whether it be an agroindustry, a cooperative or any other entity.

The third stage of production concerns the processing of the green beans whereby they are separated, identified and stored in warehouses. Quality testing is part of this stage prior to forming the stock. The Fourth stage refers to the processes of roasting and grinding the beans thereby enhancing their market value.

In spite of the fact that some coffee is traded in the third stage, a fifth stage was created referring to the trading of coffees that have run the gamut of the supply chain and arrived at the end consumer; the one who appreciates the beverage.

In addition to direct observations, semi-structured questionnaires were administered in order to find out as much as possible about the models, practices and tools used in the supply chain of specialty coffee production processing to identify how sustainability is inserted in that context. According to Gil (2002), the research protocol is one of the best ways to enhance the reliability of a case study and even more important in multiple case studies. The protocol used in this research was constructed using Figure 1 as basis.

Documental research was also one of the three techniques used in this work. It is research restricted to gathering information from documents alone and they constitute what are known as primary sources. They may be documents produced at the moment when a given fact or phenomenon occurred or afterwards (MARCONI; LAKATOS, 2003).

Yin (2001) reminds that the main recourse of the case study technique is the use of multiple sources of evidence. In short, to gather the necessary data, direct observation together with the interviews and the administration of questionnaires were made use of. The following topic sets out the results obtained.

\section{Results and discussion}

This heading covers the patterns of practices, tools and models adopted for sustainable supply chain implementation in specialty coffee production that were observed and registered during the course of the entire research.

The practices observed at the case study presented above formed the basis for the construction of Figure 2 with the aim of providing a broader, more solid analysis regarding the use of the reference framework described in the literature review.

In that scenario, governance was taken to be the essential mechanism for coordinating the sustainability approaches in the aspect of the insertion in each one of the various practices described. Furthermore, governance is considered to be the set of different ways in which individuals and institutions administer their common problems, which means that it is a continuous process that makes it feasible to accommodate conflicting interests and undertake cooperative actions (CAPORALI; VOLKER, 2004).

The practices were first grouped according to the three approaches displayed in the pillars at the base of the figure and then presented under the headings that follow below.

\subsection{Environmental and territorial issues}

In regard of environmental sustainability, various practices, mechanisms and tools that foster and consolidate the environmental sustainability of the specialty coffee production chains that were studied are presented in this section.

Lee (2008) corroborates what the case studies revealed in so far as that author considers that Sustainable Supply Chain practices consist of mechanisms that make it feasible to transfer and diffuse to the entire chain environmental management designed to improve its environmental performance. Gonçalves and Neves (2015) add that those practices can be classified under the headings of Internal Environmental Management, Eco-design and Green Operations.

The theoretical reference framework set out in this paper describes environmental management as being associated to the implantation of programs that stimulate the rational use of renewable natural resources. According to Gonçalves and Neves (2015), a successful product project of this kind depends on the cooperation between the companies in the supply chain and their partners. Such cooperation may occur in an effort to minimize waste and environmental impacts generated by the product in its entire life cycle. That is the underlying concept in Eco-design and Green Operations.

Although it was not widely referred to during the case studies, the use of alternative means of crop irrigation due to the climate characteristics of the region studied does call attention to the conservation of water resources used for production. On the other hand, it was observed and registered that the coffee growers in Minas Gerais endeavour to clean their water sources. Analysis of the certification protocols mentioned as examples in the literature review of this paper shows that cleaning water sources is one of the eight aspects verified by all of the certification schemes.

It was also noted that water is indispensable for the cleaning, drying and hulling of the coffee cherries that are to be transformed into green beans, and these last are the main product traded by the small-scale specialty coffee producers. According to the growers interviewed in Minas Gerais state, the water stemming from that processing is reused and that fact underscores the need for the property owners to plan the production inputs. 


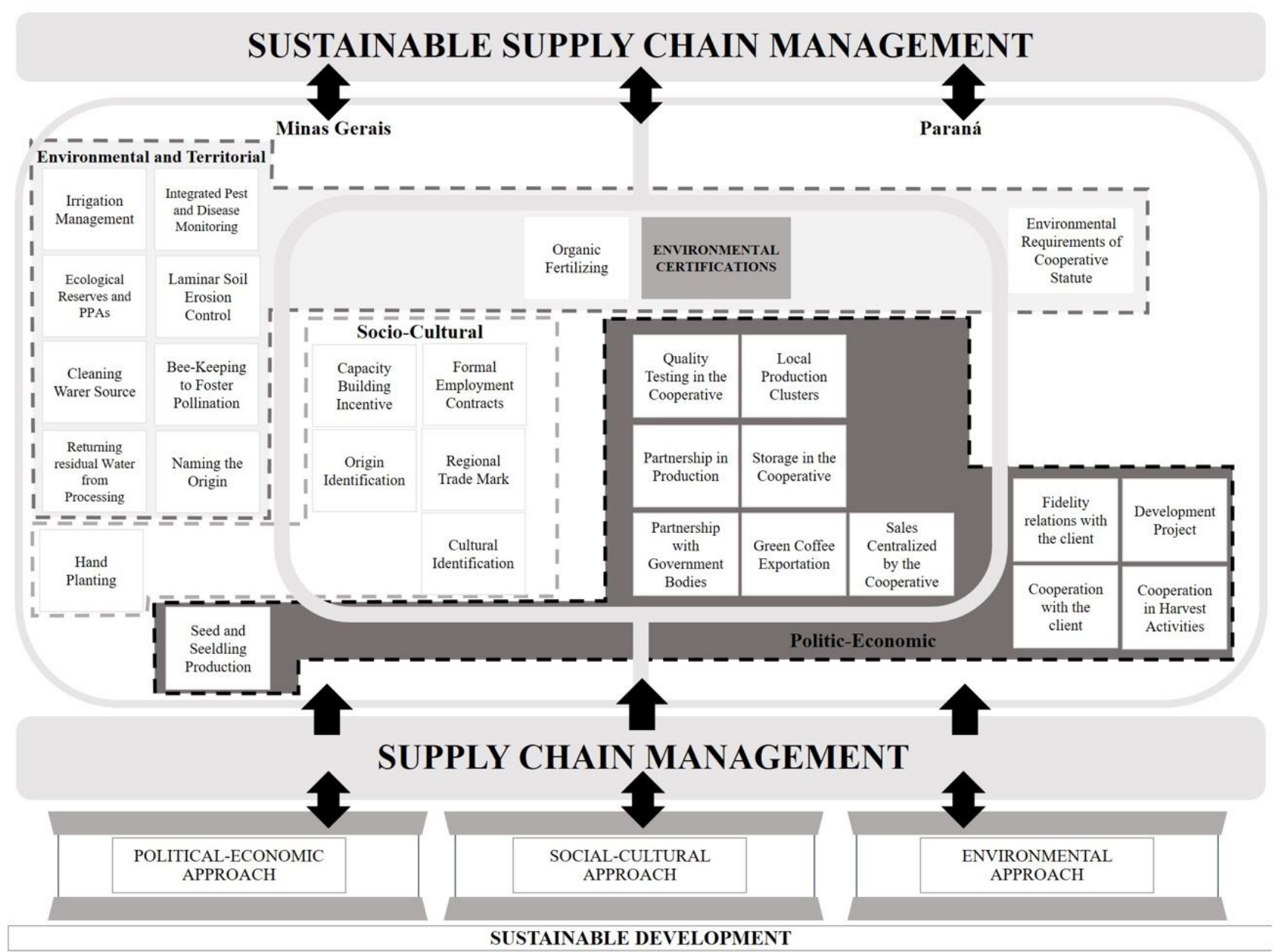

Figure 2. Concept Map of the Specialty Coffees Chain. Source: Elaborated by the authors.

Although this research did not quantify the direct impacts stemming from the use of chemical pesticides, the form of management of such chemicals may jeopardize the primordial resources for planting coffee, namely, soil and water. In that context, integrated pest and disease monitoring helps to address the problem. It is in regard to this aspect that organic production recommends the non-use of chemical mechanisms and their replacement by alternative methods for combating pests and diseases.

The information obtained from the contact with the coffee growers was that organic coffee production of specialty coffees needs to be carefully planned in order to support the lower production volumes and in that way introduce environmental benefits without negatively affecting the property's economic sustainability. The case studies did not actually engage in that kind of production but they did declare that the control of the application of agricultural chemicals applied to the production within the specifications permitted by the certification schemes had a favourable cost/benefit ratio.

Besides organic production, agro-forestry and agro-ecological practices also seek to use natural methods as far as possible but they do not guarantee the non-use of chemical products. These last two systems were cited as being possible practices to foster environmental sustainability in regard to reducing the use of resources such as chemical fertilizers and pesticides, insofar as they make use of tree planting or tree maintenance, organization of the planting layout and other methods to ensure best use of available space and resources.

Still referring to agro-forestry and agro-ecological production systems, there was mention of the use of green manure as an alternative means to enrich the soil. It involves the use of plants to improve the soil's physical, chemical and biological properties and it is an option that meets the requirement of guaranteeing environmental sustainability through adequate agricultural practice. It is therefore a 
strong ally in the endeavour to achieve the long-term maintenance of the Sustainable Supply Chain.

Natural ecosystems have evolved in such a way that they include a whole set of complex connections that minimize energy consumption and make total use of all the sub-products within the boundaries of the system in question. The rural properties in Minas Gerais mentioned laminar soil erosion control which, together with other practices mentioned under the heading of this topic, composes the set of guidelines that are designed to make the Supply Chain sustainable.

Coffee resulting from large-scale production is typified and valued according to the physical aspects of the final product such as the number of defective beans, the size of the beans and the quality of the final beverage. Social-environmental certifications are able to certify the use of agricultural practices described in this section and, accordingly, they too are important allies in the bid to introduce sustainability into the supply chains of those producing differentiated products, as is the case with specialty coffees.

As the research unfolded, it was observed that environmental criteria are often met through the intermediation of these certifications, as is the case with the use of agricultural pesticides in compliance with the doses established by the respective certification seals and again, the correct planning of the input of resources such as water in the production process.

Coffee growers usually begin their efforts to obtain certification seals with the $4 \mathrm{C}$ certification scheme and then go on to the UTZ Certified and Fairtrade schemes, and, eventually, the Rainforest Alliance certification. One example of the criteria adopted by these certification schemes in regard to environmental questions in general is the requirement that the certificate holder must have a conservation plan or participate in a regional or forest-wide biodiversity plan.

In the final analysis, according to Eisenman (2013), the only way to guarantee a sustainable future is to implement a natural organization of production that takes into account the use of renewable energy sources, the need to minimize residues, and the need to eliminate all those processes and materials that fail to contribute to the environment, specifically, non-reusable and non-biodegradable materials.

The next topic addresses the question of the practices actually observed in regard to the political-economic aspects of the properties which constitute the second aspect of the sustainability approach of this study.

\subsection{Political-economic issues}

The first production activity in the chronological sequence is the production of seeds and seedlings because they will be used for planting after the preparation of the soil and then the plants will be cultivated, the fruits harvested and so on. This is an activity that has been subsidizing to some extent the activity of actually producing coffee beans because its participation in the profits of coffee growers is increasing. Furthermore, it is a supporting activity that contributes to the sector's research scenario insofar as the case studies showed that such production is achieved with the support of the Ministry of Agriculture, Livestock and Supply (MAPA), the Minas Gerais Livestock and Agriculture Institute and the Agronomic Institute of Parana (IAPAR).

All the coffee producers that participated in the study considered that the participation of cooperatives in the chain activities was essential. They play an essential role in the entire production process because they centralize capacity building by means of the partnerships they establish, provide the necessary infrastructure for the small-scale producer (warehouses and agro-industries) and, furthermore, they trade the green beans directly with the exporting companies. That means they are capable of stimulating/encouraging intensive knowledge, strengthening the market and production and ensuring democratic governance among the associations' members.

Local production clusters that were identified in the form of geographic concentrations of coffee producers, even when they were internal to the broader economic concentrations (cooperatives), revealed themselves to be an important mechanism for strengthening the chain. Through them the producers organize themselves and deploy as many employees as necessary at harvest time, make use of the centralized installations thereby sharing the costs involved and, in addition, the clusters make it possible to create centres for the dissemination of knowledge.

It is felt that the exchanges of technical and operational information, between the community, the farmers and the cooperative, for planning purposes and to define environmental, economic and social goals directly benefits the chain. Gonçalves and Neves (2015) affirm that wherever that practice leads to joint projects being undertaken with a view to developing sustainable products and environmental innovations, then that cooperation is associated to product performance in the aspects of conformity with specifications and durability.

The Parana coffee growing region presented such practices insofar as current relations with green coffee purchaser are so close that they make it possible for the purchasers to accompany the entire production process. At the beginning of the year, purchasers present the production expectations to the exporting companies and the latter accompany and verify whether the expected production volume is going to be achieved. Also, as a means of ensuring the quality of the coffee they acquire, the purchasing companies make use of the Specialty Coffee Association of America (SCAA) table to operate that control 
and create a financial returns program based on the improved quality of the beans.

Investment recovery was another practice that contributed towards maintaining chain sustainability because it involves treating residues and other apparently useless material so that they can be re-utilized. Although this last concept does appear to be of an environmental nature, considering that these materials that are removed from the main production process and sold to other companies, they take on the nature of a strategic activity that transforms surplus or idle assets into revenue.

\subsection{Socio-cultural Issues}

Both states where the case studies were conducted presented some kind of Geographical Indication; either Named Location of Origin or Named Source of Origin. In that regard, certain practices become guaranteed by the indications especially in the socio-cultural aspects. Indications that are officially conceded to given regions not only recognize territorial participation in the composition of the product value but also the embedded socio-cultural importance. In that way they help to constitute a brand with a position in the market that is recognized by clients. The practice strengthens local communities insofar as it highlights their cultural identity by means of the coffee they produce.

Considering the scenario created by the combination of sustainable practices and the requirements for the production of specialty coffees, labour is a strategic asset when viewed in the perspective of the need for qualification. In that light, massive public and private investments in knowledge, capacity building and research are essential actions in the effort to establish production sustainability. However, what was actually observed in the case studies was a lack of any stimulus in that direction, especially considering that most of the properties maintain only 2 permanents, presumably qualified employees, but at times they hire from 20 to 80 new workers on a temporary basis.

In spite of the obvious fact that it creates employment for local people, such constant rotation is no stimulus to qualifying the employees and accordingly it fails to alter the social conditions in the areas surrounding the farms. Given the constant development of agricultural productions in the light of the quest for higher quality of the products mentioned at the beginning of this chapter, development of the communities in the vicinity of production centres should be the concern of government bodies and, indeed, of those involved in the supply chain as well. That affirmation is based on the idea that a qualified labour force offers the rural properties stability, ensuring the upward trend of their development and strengthening social sustainability.
The next topic is dedicated to final remarks and an indication of the direction for future work identified by this study.

\section{Conclusions}

In the course of this paper, unsustainable consumption and production patterns, particularly in the industrialized countries, have been portrayed as being among the major factors causing the disequilibrium that pass through the agricultural sector today and, by extension, society at large.

Against that background, coffee-growing stands out as one of Brazil's main agricultural activities and, consequently, it is highly important to discuss the adoption of increasingly Sustainable Supply Chains by that sector of the economy.

This paper has concentrated on coffee producers that own modest rural properties and given their size their main product is green coffee beans. The case studies showed that trading coffee with a higher aggregate value (roasted and ground) boosts the sales of green coffee even though the trading occurs in two distinct markets, namely coffee beans purchased in sacks ready to be processed, and cafeterias that purchase smaller quantities for their own direct consumption.

The specialty coffees studied in the present research are rated according to the SCAA table and they have a rating higher than 80 points, which is the minimum to qualify for exportation. According to those that were interviewed, current production is largely and usually shipped to those trading companies. That is only possible because the product delivered is already of a high quality. Furthermore, in this same scenarios, the farmers have managed to develop relations of fidelity with those companies whereby the later accompany production throughout the year and reward the producer financially based on the increase in quality of the product.

It was observed that farmers have managed to organize themselves and disseminate costs, strengthen cultural patterns and position themselves better in the market, together. Nevertheless, as that organization process gradually becomes more influential and the number of those associated increases, the need emerges for democratic governance and standardized procedures to ensure the uniform treatment of the products that enter and leave. There was observable participation of public and private institutions that see the production of specialty coffees as an opportunity to implement sustainability practices especially in view of the intrinsic value the product already has.

To finalize, the importance of stimulating research and intense activity to disseminate knowledge in the regions that were studied has already been mentioned in this paper. This statement stems from the fact that there are well organized groups of producers with great potential for 
developing their products, processes and consequently, their region, even more. The two regions studied produce high quality coffee that is mainly being traded for export. In that sense, there are opportunities for partnership arrangements with institutions like EMBRAPA, EMATER, IAPAR, IMA and the federal universities that would strengthen these farmers in terms of the knowledge needed to increase the value associated to their product.

Observing the coordination of sustainability concepts with Supply Chain Management practices, this paper has set out to analyse the guidelines for a sustainable supply chain for the production of specialty coffees on small farms based on a selected case study in the light of the expansion of the specialty coffees market, the mechanisms of differentiation used in coffee production and the need to adopt Sustainable Supply Chain Management practices.

To achieve the study objective, case studies were conducted as described in topic 4 and it must be underscored that during the course of the analysis it became apparent that some practices are common to the two regions studied. There are, however, other different practices adopted by the various specialty coffee supply chains but nevertheless it is still possible to state that they are sustainable.

That is because the insertion of sustainability in the chain is not, and should not be a standardized and rigid process, but, instead, a set of guidelines that can be adapted to bring the production into that alignment. It was also observed that there is a process of dissemination of a sustainability mentality in course in what is historically a very traditional production sector.

Analyses of the results and the case studies were marked by the identification of improvements in practices and of mechanisms which, although not detected in real life, are part of a whole set of improvements that could be implemented and which would help the farms to head towards sustainability.

To that end, the literature on supply chains and sustainable development was studied and six of those involved in specialty coffee production in Brazil's two major coffee growing states were observed.

There is a need to broaden the outreach of the analyses conducted in the present research and take in other Brazilian coffee growing regions to identify eventual production patterns, expand the identification of guidelines for the adoption of sustainable supply chain that have not been addressed in this project. In the sense of broadening the scope of the analyses, all the other actors that participate in the specialty coffee supply chains need to be interviewed to get a better understanding of the connections that exist among them.

In regard to the proprietors interviewed as part of the case studies, it was found that although most of them are small-scale farmers, they have mature production structures as regards production volume, relations with clients and infrastructure for commercialization of their production. In that sense this study identified an opportunity to apply the concepts delineated here to properties and regions where such structures are still only incipient.

Topic 3 presented the reference framework used for this study and it is believed that it would be possible to apply the concepts described in it to other supply chains, and not to specialty coffee chains alone; that would make the knowledge of the issues addressed here transversal and could contribute towards the inclusion of new concepts.

Finally, the analysis of the results of this study shows that there is a great need for research into ways of stimulating intensive capacity building for local labour. Which, according to what was seen in the regions that were studied, is the main factor capable of leveraging the activities as they are currently carried out. Especially in terms of enhancing product quality, improving work conditions for proprietors and employees alike, and taking greater advantage of market opportunities.

\section{Acknowledgements}

This research was supported by the Brazilian Agricultural Research Corporation (EMBRAPA) and the Brazilian Micro and Small Business Support Service (SEBRAE). The authors are grateful to the Production Engineering Department for the support.

\section{References}

ADEODATO, S. Caminhos para a mudança. Piracicaba: IMAFLORA, 2009. 152 p. Available from: <http://www. imaflora.org/index.php/biblioteca/detalhe/130>. Access in: 14 May 2015.

ALTIERI, M. Agroecologia: a dinâmica produtiva da agricultura sustentável. 3. ed. Porto Alegre: UFRGS, 2009.

ASSOCIAÇÃO BRASILEIRA DE NORMAS TÉCNICAS - ABNT. ISO/TR 14062: gestão ambiental: integração de aspectos ambientais no projeto e desenvolvimento do produto. Rio de Janeiro, 2002.

ASSOCIAÇÃO BRASILEIRA DE NORMAS TÉCNICAS ABNT. NBR 14006: sistemas de gestão ambiental: diretrizes para incorporar a concepção ecológica. Rio de Janeiro, 2011.

BOWERSOX, D.; CLOSS, D.; COOPER, M. B. Gestão da cadeia de suprimentos e logística. Rio de Janeiro: Elsevier, 2007.

BRASIL. Ministério da Agricultura, Pecuária e Abastecimento. Curso de propriedade intelectual e inovação no agronegócio: módulo II, indicação geográfica. 4. ed. Brasília, 2014. 
BRAZIL SPECIALTY COFFEE ASSOCIATION - BSCA. Cafés especiais. 2013. Available from: <http://bsca.com. br/cafes-especiais.php>. Access in: 14 May 2015.

CAFÉ DO CERRADO. Café do cerrado. [s.1.], 2015. Available from: <http://www.cafedocerrado.org/>. Access in: 20 June 2015.

CAPORALI, R.; VOLKER, P. Metodologia de desenvolvimento de arranjos produtivos locais: projeto PROMOS-SEBRAE - BID versão 2.0. Brasília: SEBRAE, 2004.

CARRARA, A. A. Chacras de café sombreado: um sistema agroflorestal Geraizeiro. Montes Claros: Centro de Agricultura Alternativa do Norte de Minas (CAA-NM), 2009.

CASTELLO-BRANCO, I. G. Relatório de viagem à região do Alto Rio Pardo no Estado de Minas Gerais. Brasília: Universidade de Brasília, 2014.

DINIZ, J. D. A. S. Avaliacão-construção de projetos de desenvolvimento local a partir da valorização dos produtos florestais da Amazônia brasileira: caso da castanha-do-brasil. 2008. 388 f. Tese (Doutorado em Desenvolvimento Sustentável)-Universidade de Brasília, Brasília, 2008.

EISENMANN, T. R. Entrepreneurship: a working definition. Harvard Business Review, 2013. Available from: < https:// hbr.org/2013/01/what-is-entrepreneurship >. Access in: 30 Apr 2015.

ELKINGTON, J. Enter the tripple bottom line. In: HENRIQUES, A.; RICHARDSON, J. Tripple bottom line: does it all add up? Londres: Earthscan, 2004. p. 1-16.

ELTAYEB, T. K.; ZAILANI, S.; RAMAYAH, T. Green supply chain initiatives among certified companies in Malaysia and environmental sustainability: investigating the outcomes. Resources, Conservation and Recycling, v. 55, n. 5, p. 495-506, 2011. http://dx.doi.org/10.1016/j. resconrec.2010.09.003.

EMPRESA BRASILEIRA DE PESQUISAAGROPECUÁRIA - EMBRAPA. Sistemas de Produção. Cultivo de café orgânico. Brasília, 2006. Available from: <https://www. spo.cnptia.embrapa.br/>. Access in: 14 May 2015.

GAMA-RODRIGUES, A. C.; BARROS, N. F.; GAMARODRIGUES, E. F. Sistemas agroflorestais: bases científicas para o desenvolvimento sustentável. Rio de Janeiro: Universidade Estadual do Norte Fluminense, 2006. 365 p.

GIL, A. C. Como elaborar projetos de pesquisa. 4. ed. São Paulo: Atlas, 2002.

GONÇALVES, L. C.; NEVES, A. G. Esverdeando a gestão da cadeia de suprimentos. Revista Mundo Logística, v. 45, p. 56-62, 2015.
GRAEDEL, A. B.; ALLENBY, B. Design for environment. New Jersey: Prentice Hall, 1995.

HADEN, S. S.; OYLER, J.; HUMPHREYS, J. H. Historical, practical and theoretical perspectives on green management: an exploratory analysis. Journal of Management History, v. 47, n. 7, p. 1041-1055, 2009. http://dx.doi. org/10.1108/00251740910978287.

KANG, S.-H. et al. A theorectical framework for strategy development to introduce sustainable supply chain management. Procedia: Social and Behavioral Sciences, v. 40, p. 631-635, 2012. http://dx.doi.org/10.1016/j. sbspro.2012.03.241.

KIECKBUSCH, R. E. Cadeias de suprimentos da indústria têxtil e de confecções do médio vale do Itajaí: comparativo entre a realidade encontrada e os referenciais teóricos. 2010. 297 f. Tese (Doutorado em Engenharia de Produção)Universidade Federal de Santa Catarina, Florianópolis, 2010.

LABEGALINI, L. Gestão da Sustentabilidade na Cadeia de Suprimentos: um estudo das estratégias de compra verde em supermercados. 2010. 242 f. Dissertação (Mestrado em Administração)-Escola de Administração de Empresas de São Paulo da Fundação Getúlio Vargas, São Paulo, 2010.

LAMBERT, M. D. Supply chain management: process, partnerships, performance. 3rd ed. Jacksonville: Supply Chain Management Institute, 2006.

LEE, S. Y. Drivers for the participation of small and medium sized suppliers in Green Supply Chain initiatives. Supply Chain Management, v. 3, n. 3, p. 185-198, 2008

LIMA, A. C. B. et al. Impacto da certificação da Rede de Agricultura Sustentável em fazendas de café. Piracicaba: Imaflora, 2008.

MANCUSO, M. A. C.; SORATTO, R. P.; PERDONÁ, M. J. Produção de café sombreado. Colloquium Agrariae, v. 9, n. 1, p. 31-44, 2013. http://dx.doi.org/10.5747/ca.2013. v09.n1.a087.

MARCONI, M. D.; LAKATOS, E. M. Fundamentos da metodologia científica. 5. ed. São Paulo: Atlas, 2003. 310 p.

MARIA, C. et al. Cadeia produtiva do café. Belo Horizonte: FEAD-MG, 2015.

MCKONE-SWEET, K. Lessons from a coffee supply chain. Supply Chain Management Review, v. 8, n. 7, p. 52-59, 2004.

MIN, H.; GALLE, W. P. Green purchasing practices of US firms. International Journal of Operations \& Production Management, v. 21, n. 9, p. 1222-1238, 2001. http://dx.doi. org/10.1108/EUM0000000005923.

MOREIRA, C. F. Caracterização de sistemas de café orgânico sombreado e a pleno sol no sul de Minas 
Gerais. 2004. 78 f. Dissertação (Mestrado em Ecologia de Agroecossistemas)-Universidade de São Paulo, Piracicaba, 2004. http://dx.doi.org/10.11606/D.91.2004.tde-29072004155514.

MOREIRA, C. F. Sustentabilidade de sistemas de produção de café sombreado orgânico e convencional. São Paulo: Universidade de São Paulo, 2009

NEGREIROS, J. R. S. Certificações para cafeicultura. Patrocínio: Educampo Café, 2011.

REDE BRASILEIRA AGROFLORESTAL - REBRAF. Manual Agroflorestal para Mata Atlântica. Rio de Janeiro, 2007. Available from: <http://www.rebraf.org.br/ cgi/cgilua.exe/sys/start.htm?infoid=221\&sid=10>. Access in: 30 Apr 2015.

REVISTA CAFEICULTURA: processo de produção de café. Rio Paranaíba, 2006. Available from: <http://www. revistacafeicultura.com.br/index.php? $\mathrm{mat}=6814>$. Access in: 20 June 2015.

SACHS, I. L'écodéveloppement: stratégie pour le XXI esi écle. Paris: Syros, 1997. 122 p.

SACHS, I. Inclusão social pelo trabalho decente: oportunidades, obstáculos, políticas públicas. Estudos Avançados, v. 18, n. 51, p. 23-49, 2004. http://dx.doi.org/10.1590/S010340142004000200002 .

SHERIFF, K. M.; GUNASEKARAN, A.; NACHIAPPAN, S. Reverse logistics network design: a review on strategic perspective. International Journal of Logistics Systems and Management, v. 12, n. 2, p. 171-194, 2012. http:// dx.doi.org/10.1504/IJLSM.2012.047220.
TEUTEBERG, F.; WITTSTRUCK, D. A systematic review of sustainable supply chain management research. Osnabruck: Betriebliches Umwelt - und nachhaltigkeitsmanagement, 2010. p. 1001-1015.

VACHON, S.; KLASSEN, R. D. Extending green practices across the supply chain: the impact of upstream and downstream integration. International Journal of Operations \& Production Management, v. 26, n. 7, p. 795821, 2006. http://dx.doi.org/10.1108/01443570610672248.

WORLD COMMISSION ON ENVIRONMENT AND DEVELOPMENT - WCED. Our common future: an overview by the World Commission on Environment and Development. In: WORLD COMMISSION ON ENVIRONMENT AND DEVELOPMENT, 10., 1987, Oslo. Proceedings... Oxford: Oxford University Press, 1987.

YIN, R. K. Estudo de caso: planejamento e métodos. Porto Alegre: Bookman, 2001.

ZHU, Q.; SARKIS, J.; LAI, K.-H. Confirmation of a measurement model for green supply chain management practices implementation. International Journal of Production Economics, v. 111, n. 2, p. 261-273, 2008. http://dx.doi.org/10.1016/j.ijpe.2006.11.029.

ZHU, Q.; SARKIS, J.; LAI, K.-H. Green supply chain management innovation diffusion and its relationship to organizational improvement: an ecological modernization perspective. Journal of Engineering and Technology Management, v. 29, n. 1, p. 168-185, 2012

ZSIDISIN, G. A.; SIFERD, S. P. Environmental purchasing: a framework for theory development. European Journal of Purchasing and Supply Management, v. 7, n. 1, p. 61-73, 2001. 